Valóságos könyvtár - könyvtári valóság. Könyvtár- és információtudományi tanulmányok 2020. Szerk. Kiszl Péter, Boda Gáborné Köntös Nelli.

Budapest, ELTE BTK Könyvtár- és Információtudományi Intézet. 2021. 403-412.

\title{
AZ ADATGAZDÁSZAT FELADATAI ÉS LEHETŐSÉGEI INTEGRÁLT KÖNYVTÁRI RENDSZEREK SZÁMÍTÓGÉPES ADATBÁZISAIBAN
}

\author{
SIMON ANDRÁS \\ Monguz Információtechnológiai Kft., közgyűjteményi szakértő, ügyfélmenedzser
}

\section{TARTALMI ÖSSZFOGLALÓ}

Az integrált könyvtári rendszerek adatbázisai sokkal több adatot őriznek, mint amennyit a felhasználók, az olvasók, sőt a könyvtárosok a kereső- és kezelőfelületeken látnak. A rendszerek tervezői és a fejlesztők a legtöbb törlési lépés során az adatokat nem törlik, csak eltüntetik a felhasználók szeme elől. Mivel az integrált rendszerek mentése során mindig az egész adatbázis mentésre kerül, ezek a felületen már nem látott, de a biztonság kedvéért megtartott adatok évtizedeken keresztül megőrződnek, sok esetben bizonyos adatok tekintetében a könyvtárban végrehajtott rendszercsere után is. Ezek az adatok, jóllehet feleslegesnek tűntek, és csak azért őrződtek meg, mert információt eldobni mindig veszélyesebb, mint tárolni, utólag nagyon sokoldalúan felhasználhatók. A tanulmány áttekinti ezen adatok lehetséges körét, az egyes integrált rendszerek archiválási, illetve adatőrzési módszereit, illetve azokat az adatokat, amelyeket, miután a rendszerben használaton kívülre kerülnek, kötelező az adatbázisból eltávolítani. Érdemes figyelembe venni azokat az okokat, melyek miatt a fejlesztők az egyes adatok végleges megsemmisítését mindig igyekeznek elkerülni. Különösen érdekes ezen adatok felhasználási módjait számba venni, így talán nem tekintjük majd elvesztegetett pénznek a számítógépes tárhelyek bővítésére fordított összegeket.

\section{Elöszó helyett. Feladatunk a digitális információ örzése és hasqnálatának biz̨tositása}

A korszerű történettudomány megjelenése óta a szakemberek elsőrangú feladatuknak tekintik, hogy minél több forrást összegyújtsenek, ôrzésükról gondoskodjanak, és mindenekelőtt saját korukról összegyújtsék és utódaikra hagyják a lehető legtöbb információt. A XX. század végén úgy látszott, az írott források gyűjtésének, ôrzésének és tárolásának feladatát a közgyűjtemények megnyugtatóan megoldották. Korunkban viszont látnunk kell, hogy mindazok a módszerek és szabályok, melyek két és fél évszázad alatt kiforrtak és elterjedtek a kézzel írott vagy nyomtatott szöveg őrzésére és szolgáltatására megváltoztak, és ezért a gyújtemények digitális kezelését és gondozását újra kell tervezni. A digitálisan tárolt információ ugyan szinte ingyen sokszorosítható, ugyanakkor roppant sérülékeny. Elveszhet a hordozó megrongálódása miatt, vagy akkor, ha az adatfolyam sérül, illetve valamiért dekódolhatatlanná válik. 
A digitális információ természete

Meg kell különböztetni, az analóg dokumentum digitalizált másolatát, a digitálisan született dokumentumtól. Az analóg dokumentum digitalizált változatát is kétféleképpen kell kezelnünk. Amennyiben az eredeti, analóg dokumentum jó állapotban van és megőrzése biztosítottnak tűnik, a digitalizált változat hosszú távú őrzése viszont nem biztosított, az csak állományvédelmi okból jött létre, akkor az eredeti, tartósan őrzendő információhordozó továbbra is az analóg dokumentum.

Az adatsorokat, melyek még analóg eszközökkel jöttek létre, de digitalizálásra kerültek, és adatbázisban, vagy táblázatos formában vannak tárolva, mindenképpen digitálisan kell megôrizni, hiszen nagy költséggel lehetne csak ezeket újra beolvastatni vagy begépelni. Különösen igaz ez arra az esetre, ha az adatokkal már valamilyen okból műveleteket végeztek.

Az elektronikus adatkezelő rendszerekből származó adatsorok már digitálisan keeletkezett információnak számítanak. Az ilyen formában létrejött és tárolt információ egyedi, pótolhatatlan, ezek esetében a sérülést, adatvesztést mindenképpen meg kell előzni. Az adatsorok dokumentált hitelessége, sértetlensége, integritása és eredetisége informatikai eszközökkel biztosítandó. Az adatokat meg kell védeni az illetéktelen használattól, és a lehetséges és szükséges mértékben szolgáltatni is tudni kell azokat. ${ }^{1}$ Egy ideje a személyes írott dokumentumok már szinte kizárólag digitálisan keletkeznek, és nem digitális változatuk már egyáltalán nem is jön létre. Gyűjtésük, nyilvántartásuk, őrzésük és hitelességük biztosítása megkülönböztetett figyelemmel végzett munkát követel a közgyújteményektől. ${ }^{2}$

\section{Új feladat, mely egyre inkább a könyvtárosokera vár: az adatgazdászat}

A kutatási tevékenység során egyre hosszabb digitális adatsorok jönnek létre, melyek keletkezése mind jobban dokumentált. Maguk az adatsorok akkor is érdekesek lesznek, amikor az azokat létrehozó projekt már lezárult, sőt akár az a szervezet, vagy intézmény is megszűnt, amelynek tevékenysége során az adatok keletkeztek. Elvárás a szolgáltató intézménnyel szemben, hogy a tartalmak állandóan elérhetők legyenek, emellett pedig metaadatokkal való megfelelő ellátással kell biztosítani a kereshetőséget és az azonosíthatóságot külső felhasználók számára is. ${ }^{3}$

A kutatási információkkal foglalkozó szakembereket a könyvtári szférában adatkönyvtárosnak (data librarian), az üzleti területen pedig inkább az adattudósnak (data scientist) nevezik. A két elnevezés nagyjából ugyanarra a szakmára vonatkozik mind feladatkör, mind pedig kompetenciák tekintetében. A számítógépek által tárolt adatsorok mennyisége és összetettsége egyre növekszik, ezeket ráadásul fel is kell dolgozni, hogy használhatók legyenek. Mindez tovább növeli az adatkönyvtárosi szakma jelentőségét. ${ }^{4}$ 
Az adatkönyvtárosi munkát a külföldi tapasztalatok szerint az akadémiai, és a közkönyvtárak eltérő módon látják el. Szakmai tekintetben az akadémiai könyvtárak járnak az élen, egy igényes és szűk kört szolgálva ki kutatási, tudományos adatokkal. A közkönyvtárak a nagyközönség egy egyre szélesedő köre számára szolgálnak információval, az üzleti, kormányzati és adminisztrációs szféra területéről. Az új feladatok ellátására az adatkezelés, az adatok strukturált és megfelelően címkézett tárolása, illetve az adatok újrahasznosítása és megosztása terén kell megfelelő készségeket kialakítaniuk az adatkönyvtárosoknak. ${ }^{5}$

Az egyre robusztusabb múszaki háttér és a növekvő igényeknek megfelelni próbáló technikai megoldások, illetve az adatkezelés egyre összetettebb feladatai miatt, egyre fontosabb a személyzet megfelelő felkészültsége. Az ezt a feladatot betöltő adatkönyvtárosok nemcsak őrzik az adatokat, hanem adott esetben elemzik és más összefüggésekkel gazdagítják is azokat Nem szabad elfelejteni azt sem, hogy az adatoknak is van életciklusuk, és a feldolgozó és szolgáltató modelleket ennek ismeretében kell kialakítani. ${ }^{6}$

Silvia Giannini és Anna Molino a kutatási adatok szolgáltatását (Research Data Service $=$ RDS) az adatgondozó könyvtáros (data curator) feladataként jelöli meg. Az adatkönyvtáros számára a közpénzen létrejött kutatási adatok kezelésénél és szolgáltatásánál a FAIR elvek - Findable, Accessible, Interoperable and Re-usable (megtalálható, elérhető, másoknak átadható, újrahaszosítható) - követése javasolt. Új technológiák és információterjesztési stratégiák alkalmazásával, az adatok széles körben megoszthatók és felhasználhatók lesznek. A könyvtárosok széles látókörük, a tudományok egészére való rálátásuk, katalogizálási és gyűjteménykezelési gyakorlatuk révén minden más szakembernél alkalmasabbak arra, hogy a jövő adatkönyvtárosai legyenek. Ezt az adatgyújtési, feldolgozási és szolgáltatási tevékenységet a szakirodalom összefoglaló néven RDM-nek (Research Data Management) nevezi. ${ }^{7}$

\section{A könyvtári rendszer adatbázisa, annak fóbb jellemzói}

Sokféle számítógépes rendszerrel találkozhattak a könyvtárosok és az olvasók az elmúlt évtizedekben. A nyolcvanas, kilencvenes évek rendszerei még nem feltétlenül voltak integráltak, tehát a gépi katalógus, a nyilvános keresőfelület, és a gyarapítási, illetve leltári nyilvántartás még nem feltétlenül használta ugyanazt az adatbázist, ezért az egyes adatállományokat különféle automatizált eljárásokkal kellett szinkronizálni. Egyes alkalmazásokat eredetileg nem is könyvtárak számára fejlesztettek ki. Az adatokat adatbáziskezelőkben, később már relációs adatbáziskezelőben tárolták, de sok rendszer kezelte az adatokat adatfájlokban vagy adatfolyamban, esetleg az alkalmazás által közvetlenül elért tároló egységen, úgynevezett raw device-on is. Idôvel általánossá váltak a relációs adatbázisokra épülő könyvtári rendszerek, melyek adatbázisa SQL (Sophisticated Query Language) alapú volt. A könyvtári rendszerek egy idő után már szabványos ( $M A R C$ formátumú) adatszerkezettel rendelkeznek, és az adatelemekből a kezelőfelület segítségével 


\section{SIMON ANDRÁS}

szemantikai háló vált építhetővé. Felépítésüktől és működésük módjától függetlenül, a könyvtári rendszerek minden esetben naplózták saját tevékenységüket, létrehoztak és tároltak tranzakciós állományokat.

\section{Adat a könyvtári rendszerben}

- katalógusadatok: bibliográfiai, példány és besorolási rekordok, szótárelemek;

- múködési adatok: partnerek, olvasók, kölcsönzési politika, előszerzeményezés, gyarapítás, érkeztetés, előjegyzés adatai;

- nyilvántartási adatok: kölcsönzési, leltárkönyvi, állományellenőrzési, törlési, pénzügyi információk;

- funkcionális adatok: a rendszer múködését, a felhasználói felületet és az adatok kezelését befolyásoló információk;

- lemásolt adatok: a gyorsaságot, biztonságot, illetve kimutatások, statisztikák készítését szolgálják;

- tranzakciós adatok: a rendszer működését naplózzák.

A szakirodalom ezek közül nem mindet tartja szükségesnek tartósan megőrizni. D. RileyReid tanulmányában, adminisztratív, technikai, leíró (katalógus) és strukturális metaadatokról tesz említést. Ezek közül szerinte az adminisztratív és a leíró metaadatokat kell egy migráció esetén az új rendszerbe átmozgatni, illetve tartósan ôrizni az adatbázis integritásának hosszú távú biztosítása céljából. ${ }^{8}$

A könyvtári adatbázisban a bibliográfiai és besorolási rekordok között kiépült szemantikai háló átnyúlhat az adatbázis határán, és külső adatokra vonatkozó utalásokat tartalmazhat.' A lemásolt adatok külső adatforrásra, általában névtér vagy tezaurusz jellegú információra mutató speciális csoportjának szerepe, korszerű rendszerekben már meghatározó is lehet. ${ }^{10} \mathrm{~A}$ lemásolt, hosszú távú megőrzésre a szakirodalom által nem javasolt adatok egy másik csoportját képezik az indexállományok. Ezek a keresést és a böngészést támogatják az adatbázisban. Különösen nagy hozzáadott értéket képviselnek az adatbázisba betöltött teljes szöveges tartalmak szóindexei. ${ }^{11}$ Az indexek tervezése, kialakítása nem automatizálható, futtatásuk jelentős gépidőt igényel. Az adatbázisok nemcsak az indexállományt magát tárolják, hanem az index elkészítési technikáját is, függvények, tárolt eljárások, az adatbázis elemekhez illesztett rövid programok, úgynevezett triggerek vagy adatbázison kívüli programkódok formájában. Az indexek előállításának módját mindenképpen dokumentálni, és ezt a dokumentációt őrizni kell, magukkal az indexállományokkal pedig a hosszú távú megőrzésre szánt adatbázis-mentéseket nem szabad megterhelni. ${ }^{12}$

\section{Mi történhet az adatbázissal?}

Az adatbázisok őrzése, integritásuk biztosítása elsőrangú feladat a modern, minden elemében az informatikára építő könyvtári gyakorlatban. A digitális adatok megőrzése esetében, meg kell különböztetnünk a preventív megőrzést (preventive preservation) 
és a helyreállító megőrzést (curative preservation). Az előbbi feladat informatikai rendszerünk nemkívánatos változásokra való felkészítését, az utóbbi a hardveres vagy szoftveres okokból már bekövetkezett káresemény utáni helyreállítást jelenti. A helyreállítás nemcsak magát az adatfolyamot (bitstream), illetve az adatok közötti összefüggéseket kell hogy érintse, hanem múködőképesnek kell lennie az alkalmazásnak is, amely az adatfolyamot fel tudja olvasni és a felhasználó számára, valamilyen perifériára, jellemzően egy képernyőre emberi szemmel felfoghatóan ki tudja szerkeszteni. Ez a feladat az idő múlásával és az alkalmazások változásával, elavulásával egyre több gondot tud okozni, ez teszi a hosszú távú megőrzést a napi használat számára való tárolásnál lényegesen költségesebbé. ${ }^{13}$

Az adatbázist számos behatás érheti, ezek vagy előre tervezettek, vagy nem. Ez utóbbiak, mivel a nem tervezett változás egy múködő rendszer esetében nem jelenthet jót, minden esetben baleset jellegűnek tekintendők. ${ }^{14}$

\section{Tervezett változások}

- Frissítés: ennek során a rendszer megváltozik, de a változás nem jelentős, az adatokat magukat ritkán érinti.

- Verziócsere: jelentôs változás történik a rendszerrel, adott esetben az adatok is módosulhatnak.

- Áttöltés másik rendszerbe: az adatokon az illető idegen rendszer múködésének megfelelően jelentős változtatások történnek. Migrációról akkor beszélünk, ha maga az adatstruktúra változatlan marad, míg konverzióról akkor, ha az adatoknak, illetve azok kapcsolati hálójának szerkezete is jelentős átalakuláson megy át.

\section{Nem tervezett változás}

- Az adatbázis helyreállítása valamilyen sérülés, káresemény után. Ekkor az adatbázist, vagy annak sérült elemeit az adatromlás elôtti utolsó állapotban kísérlik meg az adatbázis karbantartói helyreállítani. Az adatbázis, illetve az adatok szerkezetében ilyenkor nem következhet be változás.

\section{Az adatok sorsa változás esetén}

Szállítói garancia vonatkozik a teljes adatbázisra a rendszerek frissítésénél, verzióváltásnál. Az alábbi adatokat sértetlenül helyre kell állítani, más rendszerbe való áttöltés és katasztrófa utáni helyreállítás esetében:

- katalógusadatok;

- kurrens nyilvántartási adatok;

- kurrens gyarapítási adatok;

- kurrens olvasói és kölcsönzési adatok;

- tranzakciós adatok. 


\section{SIMON ANDRÁS}

Ezek közül a régebbi gyakorlat szerint is, amikor egy könyvtár gépi rendszerét egy másik informatikai megoldásra cserélte, áttöltötték a kurrens katalógus tartalmát és az érvényes tagsággal rendelkező olvasók adatait.

Kinyomtatják még ma is, tehát nem csak digitális formában tárolják a nyilvántartási adatok egy részét, az apasztás, pénzügy, állományellenőrzés adatait, illetve alkalmanként a leltárkönyvet is. Amennyiben a nyomtatási kötelezettség ezekre a dokumentumokra megszűnik, a tartós megőrzést ezen állományokra is biztosítani kell.

A rendszercserét tehát nem, de a frissítést és a verziócserét átvészelik az alábbi adatok:

- nem kurrens kölcsönzések, tehát ahol a könyveket az olvasók már visszahozták;

- előszerzeményezési információk, ha azokat nem követte tényleges beszerzés;

- nem kurrens (tehát teljesült, vagy lemondott) gyarapítás;

- tranzakciós információk, melyek a rekordok keletkezésére és módosulására vonatkoznak.

Önálló információt nem hordoznak, ezért ezek tartós, hosszú távú, a könyvtári rendszer vélelmezett élettartamán túlmutató őrzése, illetve más rendszerbe való áttöltése takarékossági okokból nem javasolt:

- funkcionális adatok: a rendszer működésére vonatkozó információkat nem a mentett adatbázisnak, hanem a szoftver dokumentációjának kell tartalmaznia;

- lemásolt adatok.

Mire használhatjuk az integrált könyvtári rendszerben megörzött, a napi könyvtárhas₹nálatot már nem segito" adatokat?

Azokat az adatokat, melyek már nem szolgálják a napi múködést, illetve az intézmény nyilvántartási kötelezettsége sem vonatkozik rájuk, és a könyvtári katalógusnak sem részei, számos területen lehet hasznosítani:

- könyvtárhasználati vizsgálatok;

- könyv- és könyvtártörténeti vizsgálódások;

- gazdasági, pénzügyi kimutatások készítése.

A nem kurrens kölcsönzési és beszerzési adatok a könyvtári statisztikai adatszolgáltatás alapját képezik. A beszolgáltatott adatokat a Könyvtári Intézet Kutatási és Szervezetfejlesztési Osztálya fogadja és tárolja. Az intézmény a könyvtári tevékenységek legfőbb mutatóinak, a beiratkozottak, a használók és a használatok (látogatás, kölcsönzés, helyben használat és távhasználat) számának elemzése során megállapított trendekről, a rendszerek, adatbázisok igénybevételéről tájékoztatást tud adni megrendelőinek. ${ }^{15}$

A könyvtárhasználati kutatások során természetesen ügyelni kell arra, hogy az olvasók személyes adatait a könyvtár a GDPR szabályozások értelmében, csak addig tárolhatja, ameddig az olvasó könyvtári tagsága fennáll, illetve ameddig a vonatkozó jogszabályok azt megengedik. ${ }^{16}$ A GDPR szabályozás szellemében, az olvasói rekordot tagságának megszűnése után törölni kell, és az eredeti rekordnak az olvasó személyének 
azonosítására nem alkalmas elemeiből, anonimizált felhasználói tranzakciós rekordot kell képezni. Ezen rekordok képzésének köszönhetően, a kölcsönzési tranzakciókat őrző könyvtári rendszer adatbázisának integritása megmarad. Az ebben található adatokat, a későbbi kutatások fel tudják használni. ${ }^{17}$

A könyvtártörténeti kutatások számára érdekesek lehetnek a számítógépes leltárkönyvben törölt státuszúra állított dokumentumok példány- és bibliográfiai rekordok adatai, illetve a régebbi, már rendezett, leszállított, kifizetett rendelési és lezárt pénzügyi évhez tartozó könyvelési adatok.

Az adatok ôrzésének ára

Az adatok tárolásának és őrzésének költségei vannak, ezek az adattömeg növekedésével egyre feltűnőbben jelentkeznek. A tárolóterület biztosítása az ezredforduló óta egyre jelentősebb költséget jelent, ez az emelkedő kereslettel, a digitalizált képfájlok számának és átlagos méretének állandó növekedésével magyarázható. A lemezterülettel és a mentésre fordított emberi és gépidővel való takarékosság egy módja a tárolt adatfájlok méretének csökkentése, valamilyen technikai beavatkozás segítségével. Ha az adatokat, annak érdekében, hogy kevesebb helyet foglaljanak módosítjuk, információt veszíthetünk, de a visszakeresés könnyebb, az ôrzés olcsóbb lesz, és a kezelés és gondozás is kevesebb munkát igényel majd.

Az adatok hosszú távú tárolását, és főként annak költségeit körültekintően kell megtervezni, főként, mert a hosszú távú megőrzés lényegesen költségesebb, mint a rövid távú, a napi használathoz tartozó őrzés. ${ }^{18} \mathrm{~A}$ digitális tartalmak hosszú távú őrzése nem egy alkalmi projekt, melyet az intézmény, amennyiben egyéb szempontok engedik, felvállal, hanem egy állandó költségfaktort képző, a közgyújteményi alaptevékenységekhez tartozó feladat. A szükséges tartalmakat nemcsak gyűjteni, rendezni, eltárolni és szükség esetén migrálni kell tudnia az informatikai alkalmazásnak, hanem hosszú távon is teljes épségben, olvashatóan és újrahasználhatóan kell tudnia megörizni azokat. Kiemelt gonddal kell kezelni a digitálisan született tartalmakat, illetve azokat az eseteket, amelyeknél nem áll rendelkezésre jó fizikai állapotú eredeti tartalom. ${ }^{19}$

A hosszú távú megôrzés (LTP - Long Time Preservation / LZ A Langzeitarchivierung) a nyugati szakirodalomban széles körben tárgyalt folyamatát a Guideline zur Langzeitarchivierung címú tanulmány három részre bontja. Ezek: az adatfolyam fizikai sértetlenségének biztosítása, az adatok alkalmazások számára való helyreállíthatóságának megoldása, illetve az adatok kereshetőségének lehetővé tétele. Ehhez szükséges a megfelelő hardverek és szoftverek múködtetése, a megfelelően képzett személyzet alkalmazása, és a tartósan múködő intézményi háttér. ${ }^{20}$

A hosszú távú megőrzés alapvető technikai és módszertani elveit az OAIS referencia modell (Reference Model for an Open Archival Information System) írja le. ${ }^{21}$ Az adatok hosszú távú őrzése a digitális kor memóriaőrző intézményei számára elsőrendű feladat lett, és a LAM (Libraries, Archives, Museums) szektor számára közös európai projekt jött létre, 


\section{SIMON ANDRÁS}

a Preforma, melyet a Svéd Királyi Levéltár koordinál. ${ }^{22}$ Nem tekinthetjük véletlennek, hogy egy levéltár kapta meg a koordinátori feladatot, mert a digitálisan született és éppen ezért legsérülékenyebbnek tekintett dokumentumok nagy része a levéltárakban található.

A hosszú távú megőrzés egyik mintaprojektje, az Osztrák Állami Levéltár (Langzeitarchiv des Österreichischen Staatsarchivs) vezetésével valósul meg. A digitális dokumentumokat először az ELAK rendszerben (Dokumente aus dem Elektronischen Akt) tárolják, és a hatósági előírásokat követve a tartósan megőrzendő, „archiválásra érdemes” tételeket a Preservica célszoftverrel archiválják. ${ }^{23}$

\section{Összegzés}

Fontos feladat, hogy a könyvtári adatbázisokban megkülönböztessük a pótolhatatlan információt tartalmazó primer és a származtatott adatokat tartalmazó szekunder adatokat. Az adatok hosszú távú megőrzése roppant költséges feladat, ezért ennek biztosításakor elsôsorban a primer adatok ôrzésére kell az erőforrásokat összpontosítani. A primer adatok a számítógépes könyvtári katalógusban az integrált rendszer múködése során a felhasználói felületen történt adatbevitel során jönnek létre, de a különféle üzemeltetési eljárások során sok esetben eltűnnek a felhasználó elől. Az adatok fennmaradásának biztosításához ezért informatikai tudás szükséges. Megkülönböztetett figyelmet kell fordítani a primer adatok leválogatására és őrzésére, ha a számítógépes katalógust leállítják, vagy a könyvtár megszűnése, vagy az állomány már digitális katalógusba való áttöltése, illetve a rendszer cseréje miatt.

\section{Jegyzetek és irodalom}

1. FRÖHLICH, Susanne: Der Weg ist das Ziel! Planung und Umsetzung digitaler Archivprojekte. $=$ Mitteilungen der VÖB, Bd. 66. Nr. 1. 2013. 133-144. p. Forrás: https://doi. org/10.31263/voebm.v70i1 [2020. április 22.]

2. RAYWARD, W. Boyd: Electronic information and the functional integration of libraries, museums, and archives. = HIGGS, Edwars (ed.): History and Electronic Artefacts. Oxford, Clarendon Press, 1998. 215. p. Forrás: https://www.ideals.illinois.edu/handle/2142/9474 [2020. április 22.]

3. LADD, Marcus: Access and use in the digital age: a case study of a digital postcard collection. = Walter Havighurst Special Collections, Miami University, Oxford, Ohio, USA, 2015.

4. KOLTAY Tibor: Adatkönyvtáros vagy adattudós. Néhány gondolat a különbségekről és hasonlóságokról. = Tudományos és Múszaki Tájékoztatás, 65. évf. 10. sz. 2018. 518-522. p.

5. YOON, Ayoung [et al.]: Library capacity for data curation services: a US national survey. $=$ Library Hi Tech, Vol. 37. No. 4. 2019. 811-828. p. Forrás: https://doi.org/10.1108/LHT12-2018-0209 [2020. április 22.] 
6. TAMMARO, Anna M. [et al.]: Data curator's roles and responsibilities: an international perspective. $=$ Libri, Vol. 69. No. 2. 2019. 89-104. p. Forrás: https://doi.org/10.1515/libri2018-0090 [2020. április 22.]

7. GIANNINI, Silvia - MOLINO, Anna: The data librarian: myth, reality or utopia? = The Grey Journal, Vol. 15. No. 1. 2019. 7-22. p.

8. RILEY-REID, Trevar D.: The hidden cost of digitization - things to consider. $=$ Collection Building, Vol. 34. No. 3. 2015. 89-93. p. Forrás: https://doi.org/10.1108/CB-01-20150001 [2020. április 22.]

9. FÜLÖP Endre: A szemantikus háló két fogalma, a katalógusok új generációja és a könyvtárak szerepe. $=$ Tudományos és Múszaki Tájékoztatás, 65. évf. 7/8. sz. 2018. 401-408. p.

10. SIEGMÜLLER, Renate: Verfahren der automatischen Indexierung in bibliotheksbezogenen Anwendungen. = Berliner Handreichungen zur Bibliotheks- und Informationswissenschaft, Heft 214. 2007. 7. p. Forrás: http://www.ib.hu-berlin.de/ kumlau/handreichungen/h214 [2020. április 22.]

11. SIEGMÜLLER, Renate: i. m. 59. p.

12. SIEGMÜLLER, Renate: i. m. 12. p.

13. TRIPATHI, Sneha: Digital preservation: some underlying issues for long-term preservation. = Library Hi Tech News, Vol. 35. No. 2. 2018. 8-12. p. Forrás: https://doi.org/ 10.1108/LHTN-09-2017-0067 [2020. április 22.]

14. LENGYEL Monika - SIMON András: „Rendszerváltás” a hazai könyvtárakban - divathullám vagy kényszer? = Tudományos és Műszaki Tájékoztatás, 50. évf. 8. sz. 2003. 313-317. p.

15. TÓTH Máté: Könyvtárhasználat és információkeresés - egy országos reprezentatív felmérés eredményei. In: Béres Judit (szerk.): Könyvtárhasználat és az információkeresés fejlesztése. Budapest, Fővárosi Szabó Ervin Könyvtár, 2019. 204-260. p. Forrás: http://www. azenkonyvtaram.hu/documents/11543/49997/A+k\%C3\%B6nyvt\%C3\%A1rhaszn\%C3 $\%$ A1lat $+\% \mathrm{C} 3 \% \mathrm{~A} 9 \mathrm{~s}+\mathrm{az}+$ inform $\% \mathrm{C} 3 \% \mathrm{~A} 1 \mathrm{ci} \% \mathrm{C} 3 \% \mathrm{~B} 3 \mathrm{keres} \% \mathrm{C} 3 \% \mathrm{~A} 9 \mathrm{~s}+$ fejleszt $\% \mathrm{C} 3 \% \mathrm{~A}$ 9se/ebf84094-e410-41dc-8859-804b1daae17c [2020. április 22.]

16. TÓSZEGI Zsuzsanna: Az Európai Unió általános adatvédelmi rendelete, a GDPR - 1. rész: Alapfogalmak, alapelvek. = Könyvtári Figyelő, 65. évf. 1. sz. 2019. 9-35. p. és TÓSZEGI Zsuzsanna: Az Európai Unió általános adatvédelmi rendelete, a GDPR. 2. rész: A könyvtárak adatkezelői szerepköre. = Könyvtári Figyelő, 65. évf. 2. sz. 2019. 195-211. p.

17. SIMON András: Integrált könyvtári rendszerben tárolt tranzakciós rekordok felhasználása a könyvtárhasználat statisztikai elemzésére. = Tudományos és Műszaki Tájékoztatás, 66. évf. 12. sz. 2019. 683-693 p.

18. RILEY-REID, Trevar D.: The hidden cost of digitization - things to consider. $=$ Collection Building, Vol. 34. No. 3. 2015. 89-93. p. Forrás: https://doi.org/10.1108/CB-01-2015-0001 [2020. április 22.]

19. FRÖHLICH, Susanne: i. m.

20. BIRKNER, Michael [et al.]: Guideline zur Langzeitarchivierung. = Mitteilungen der VÖB, Bd. 69. Nr. 1. 2016. 41-57. p. Forrás: https://doi.org/10.31263/voebm.v69i1.1396 [2020. április 22.]

21. Az OAIS referencia modell honlapja. Forrás: http://www.oais.info [2020. április 22.] 


\section{SIMON ANDRÁS}

22. Preforma: D8.1R2 Competitive Evaluation Strategy/ Revision: Final 1.00, 26 October 2016, Stockholm. Forrás: https://www.digitalmeetsculture.net/article/d8-1r2-competitiveevaluation-strategy [2020. április 22.]

23. MAYER, Adelheid: Workshop „Software-Lösungen zur Langzeitarchivierung und Repositorien-Verwaltung aus Anwendersicht”. = Mitteilungen der VÖB, Bd. 69. Nr. 1. 2016. 151-154. p. Forrás: https://doi.org/10.31263/voebm.v69i1 [2020. április 22.]

Simon András - 1993-ban végzett az ELTE BTK történelem-könyvtár szakán. Az ELTE BTK Irodalomtudományi Doktori Iskola Könyvtártudományi Doktori Programjának doktorandusz hallgatója. 1992 óta dolgozik magyar könyvtárakban a könyvtárautomatizálás területén. 1999 és 2002 között a MOKKA rendszergazdája. 2002-től alvállalkozóként, később alkalmazottként működik együtt az MTA SZTAKI ASZI osztályával, majd a szegedi Monguz Kft.-vel integrált könyvtári rendszerek tervezése, fejlesztése, ügyféltámogatása és forgalmazása területén. 